Research Paper

\title{
Thermotolerant and mesophylic fungi from sugarcane bagasse and their prospection for biomass-degrading enzyme production
}

\author{
Bruna Silveira Lamanes dos Santos, Arthur Filipe Sousa Gomes, \\ Emanuele Giuliane Franciscon, Jean Maikon de Oliveira, Milla Alves Baffi \\ Instituto de Ciências Agrárias, Universidade Federal de Uberlândia, Uberlândia, MG, Brazil.
}

Submitted: May 10, 2014; Approved: November 16, 2014.

\begin{abstract}
Nineteen fungi and seven yeast strains were isolated from sugarcane bagasse piles from an alcohol plant located at Brazilian Cerrado and identified up to species level on the basis of the gene sequencing of 5.8S-ITS and 26S ribosomal DNA regions. Four species were identified: Kluyveromyces marxianus, Aspergillus niger, Aspergillus sydowii and Aspergillus fumigatus, and the isolates were screened for the production of key enzymes in the saccharification of lignocellulosic material. Among them, three strains were selected as good producers of hemicellulolitic enzymes: A. niger (SBCM3), A. sydowii (SBCM7) and A. fumigatus (SBC4). The best $\beta$-xylosidase producer was $A$. niger SBCM3 strain. This crude enzyme presented optimal activity at $\mathrm{pH} 3.5$ and $55^{\circ} \mathrm{C}(141 \mathrm{U} / \mathrm{g})$. For $\beta$-glucosidase and xylanase the best producer was A. fumigatus SBC4 strain, whose enzymes presented maximum activity at $60{ }^{\circ} \mathrm{C}$ and $\mathrm{pH} 3.5(54 \mathrm{U} / \mathrm{g})$ and $4.0(573 \mathrm{U} / \mathrm{g})$, respectively. All these crude enzymes presented stability around $\mathrm{pH} 3.0-8.0$ and up to $60^{\circ} \mathrm{C}$, which can be very useful in industrial processes that work at high temperatures and low $\mathrm{pHs}$. These enzymes also exhibited moderate tolerance to ethanol and the sugars glucose and xylose. These similar characteristics among these fungal crude enzymes suggest that they can be used synergistically in cocktails in future studies of biomass conversion with potential application in several biotechnological sectors.
\end{abstract}

Key words: $\beta$-glucosidase, $\beta$-xylosidase, xylanase, Aspergillus, sugarcane bagasse.

\section{Introduction}

Agro-industrial wastes such as sugarcane bagasse, wheat bran and corn straw have been recognized as important renewable sources of biofuels and other value-added products (Moretti et al., 2012). These residues are widely available in Brazil and are composed of the polymers cellulose, hemicellulose and lignin. In recent years, there has been an increasing trend towards more efficient exploitation of these by-products. Due to their heterogeneity, several microbial enzymes (cellulases and hemicellulases) with specific modes of action are used to catalyze the hydrolysis of these polymers (Matkar et al., 2013).

Cellulose is degraded by the synergistic action of three cellulases: exoglucanases, endoglucanases and cellobiases, which release cello-oligosaccharides and cellobiose, respectively. Exoglucanases or avicelases (EC 3.2.1.91) are responsible for removing the cellobiose from the nonreducing ends and endoglucanases (EC 3.2.1.4) perform the cleavage from the amorphous parts of cellulose in order to reduce the polymerization level. Lastly, $\beta$-glucosidases or celobiases (EC 3.2.1.21) catalyze the hydrolysis of cellobiose in free glucose (Martins et al., 2008). Two hemicellulases have a significant role for the depolymerization of hemicellulose: xylanases and the $\beta$-xylosidases. The former are applied for xylan hydrolysis, the main polysaccharide of hemicellulose and $\beta$-xylosidases act after the hydrolysis of xylan by xylanases, cleaving oligomers of $\beta$-D-xylopyranosyl and xylobiose in free xylose (Polizeli et al., 2005). Thus, the cooperative action of cellulases and hemicellulases from microbial origin is needed in order to achieve effective biomass hydrolysis from the residues (Polizeli et al., 2005). 
In industrial processes, thermotolerant hemicellulases and cellulases are preferable since high temperatures are required to increase the solubility of substrates, to reduce viscosity and to reduce risk of contamination (Facchini et al., 2011). As a result, the search for thermophilic microorganisms with the potential for the synthesis of such enzymatic complexes has increased considerably in recent times, mainly filamentous fungi, which have been the most employed for it (Moretti et al., 2012).

At present, molecular methods have been largely employed for the identification of microorganisms since they are independent of culture conditions, accurate and rapid (Baffi et al., 2010). Among them, ribosomal DNA sequencing has been one of the main tools for the classification of fungi strains (Baffi et al., 2012). Accordingly, the aim of this study was to identify the fungal microbiota isolated from sugarcane bagasse piles from Brazilian Cerrado by rDNA sequencing. Moreover, we intended to select novel strains able to synthesize thermotolerant key enzymes in the process of degrading lignocellulosic material from agro-industrial residues. The physicochemical properties of the selected enzymes were also investigated.

\section{Materials and Methods}

\section{Isolation of microorganisms}

Isolation of fungal strains was performed from piles of sugarcane bagasse obtained from the Alvorada Plant, from the mesoregion of Triângulo Mineiro and Alto Paranaíba (Araporã, west of the state of Minas Gerais, Brazil) which lies at $18^{\circ} 26^{\prime} 13^{\prime \prime} \mathrm{S}$ and $49^{\circ} 11^{\prime} 13^{\prime \prime} \mathrm{W}$, with a tropical climate and is part of Brazilian Cerrado.

Ten collecting points from the internal parts of different piles, where the temperatures are elevated, were randomly chosen to collect samples of thermophilic fungi. For the isolation of mesophilic fungal strains, ten random points were also selected but, from the external parts of the piles. The samples $(0.5 \mathrm{~g})$ were harvested and homogenized in a sterile broth containing $(\mathrm{g} / \mathrm{L})$ : cardboard, 5.0; $\left(\mathrm{NH}_{4}\right) 2 \mathrm{SO}_{4}, 1.4 ; \mathrm{K}_{2} \mathrm{HPO}_{4}, 2.0 ; \mathrm{CaCl}_{2}, 0.3$; peptone, 2.0; yeast extract, 2.0; glucose, 1.0 ; urea, $0.3 ; \mathrm{MgSO}_{4} .7 \mathrm{H}_{2} \mathrm{O}$, 0.2 ; and $10.0 \mathrm{~mL}$ of nutrient solution which consisted of (mg/L): $\mathrm{FeSO}_{4} .7 \mathrm{H} 2 \mathrm{O}, 5.0 ; \mathrm{MnSO}_{4} \cdot \mathrm{H}_{2} \mathrm{O}, 1.6 ; \mathrm{ZnSO}_{4}$ $7 \mathrm{H}_{2} \mathrm{O}, 1.4 ; \mathrm{CoCl}_{2}, 2.0$, at $\mathrm{pH}$ 5.0. The inoculated medium was incubated under shaking at $45{ }^{\circ} \mathrm{C}$ for the isolation of thermophilic strains and at $30{ }^{\circ} \mathrm{C}$ for mesophilic fungi, for 72 hours. Afterwards, aliquots of liquid medium were streaked on Petri dishes containing Agar Sabouraud medium (45.0 g/L), with chloramphenicol and ampicillin $(0.2 \mathrm{~g} / \mathrm{L})$ to inhibit bacterial contamination, and incubated at 45 or $30^{\circ} \mathrm{C}$ (thermophilic and mesophilic strains, respectively), for 24 to 96 hours.

When colonies appeared, they were subcultured onto fresh plates containing the same medium and allowed to grow for several days. This process was repeated until pure cultures were obtained. The stock cultures were maintained, with periodical subcultures, in Agar Sabouraud medium, at room temperature. Each isolate was also conserved in Castellani flasks with MilliQ sterile water for subsequent studies (Castellani, 1939).

All morphologically contrasting colonies were identified by conventional and molecular methods. The molecular identification of the isolated strains was performed firstly by polymerase chain reaction (PCR), followed by gene sequencing of the ITS intergenic region of ribosomal DNA.

\section{DNA extraction}

Each strain was grown on YPD medium ( $1 \%$ yeast extract, $2 \%$ glucose and $2 \%$ peptone) for 48 hours at 30 and $45{ }^{\circ} \mathrm{C}$ (mesophylic and thermophylic strains, respectively). Genomic DNA was extracted from mycelium using the DNAeasy Plant Mini Kit (Qiagen, USA). Fungal mycelia were macerated in liquid nitrogen using a mortar and pestle. Powdered samples were transferred to microcentrifuge tubes and the procedure was carried out according to the manufacturer's protocol. Isolated DNA from each strain was examined on $1 \%$ agarose gel using $5 \mu \mathrm{L}$ of DNA, $2 \mu \mathrm{L}$ of Load Dye and $1.5 \mu \mathrm{L}$ of SYBR Green I fluorescent DNA binding dye and stored at $-20{ }^{\circ} \mathrm{C}$.

\section{PCR amplification}

Amplification of the internal transcribed spacer (ITS) region of the ribosomal DNA was performed according to Baffi et al. (2012). The forward primer was ITS1 (5 TCC GTA GGT GAA CCT GCG G 3) and the reverse primer was ITS4 (5 TCC TCC GCT TAT TGA TAT GC 3). Polymerase chain reaction (PCR) was performed in a final volume of $50 \mu \mathrm{L}$, and contained $0.2 \mathrm{mM}$ of each dNTP, $1 \mathrm{x}$ PCR buffer with $\mathrm{MgCl}_{2}, 1.0 \mathrm{U}$ Taq DNA polymerase, $0.5 \mu \mathrm{M}$ of each primer, and 10-50 ng of total DNA template. PCR amplification was carried out in a thermal cycler (MyCycler TM Thermal Cycler, Bio-Rad, USA) with the following cycling parameters: an initial denaturation at $95^{\circ} \mathrm{C}$ for $5 \mathrm{~min}$, followed by 33 cycles of denaturation at $95{ }^{\circ} \mathrm{C}$ for $1 \mathrm{~min}$, primers annealing temperature at $52{ }^{\circ} \mathrm{C}$ for $1 \mathrm{~min}$ and extension at $72^{\circ} \mathrm{C}$ for $1 \mathrm{~min}$, followed by a final extension at $72{ }^{\circ} \mathrm{C}$ for $5 \mathrm{~min}$. PCR products were checked by electrophoresis on $1.5 \%$ agarose gels $(5 \mu \mathrm{L}$ of each sample $+2 \mu \mathrm{L}$ of Load Dye and 1.5 $\mu \mathrm{L}$ of SYBR Green I fluorescent DNA binding dye). After electrophoresis, the gel was visualized under a UV transilluminator.

\section{PCR products' purification}

The amplified products were purified using a kit for PCR products (GeneJet PCR purification kit, Fermentas). After purification, the quality of the purified PCR products was evaluated through electrophoresis on $1 \%$ agarose gels 
and the quantity determined using a NanoDrop ND-1000 UV-Vis spectrophotometer.

\section{Sequencing of 5.8S-ITS rRNA region}

Sequencing of purified PCR products was performed on an ABI 3730 XL automated sequencer (Applied Biosystems) by a commercial laboratory (Macrogen Sequencing Service, Korea). After sequencing, chromatograms were visually checked and edited using the BioEdit software (DNAstar Lasergene software, Madison, WI, USA; http://www.mbio.ncsu.edu/BioEdit/bioedit.html). The obtained sequences of the ITS1-5.8-ITS2 region were compared with sequences available in the GenBank database (National Center for Biotechnology Information NCBI), using the BLASTn algorithm software (Local Alignment Search tool) (http://blast.ncbi.nlm.nih.gov). Sequences for the 5.8S-ITS rDNA region with 99\% nucleotide identity or higher were considered to correspond to the same species.

\section{S rDNA region sequencing analysis}

Total DNA samples from each strain were also submitted to PCR amplification and sequencing for the 26S (D1/D2) rDNA region. Specific amplifications were attempted from pure cultures, using the pair of primers ITS 1 5' (TCC GTA GGT GAA CCT GCG G) 3' and LR 3R 5' (GGT CCG TGT TTC AAG AC) 3'. The PCR conditions for $26 \mathrm{~S}$ region were the same as described for 5.8S-ITS rRNA region sequencing but the annealing temperature was increased to $54^{\circ} \mathrm{C}$ (Baffi et al., 2010). The obtained sequences were deposited in the GenBank data library under accession numbers.

\section{Morphological identification}

Strains with less than $97 \%$ similarity with published sequences in the GenBank database were submitted to identification by morphological examination on a stereoscope. The macroscopic variables analyzed included: mycelium aspect, colony diameter, spore coloration, obverse and reverse mycelium color, degree of sporulation and other characteristics (Pitt and Hocking, 1997). To examine fungal structures, mycelia were examined in a lactophenol cotton blue solution using a light microscope. These procedures allowed identification up to genus level.

\section{Enzyme production}

The biosynthesis of cellulases and hemicellulases was carried out according to Moretti et al. (2012), with some modifications. The fungal strains were cultivated by solid-state fermentation (SSF) using a mixture of wheat bran and sugarcane bagasse as carbon sources $(1: 1 \mathrm{w} / \mathrm{w})$. The wheat bran and sugar cane bagasse were washed and dried $\left(55^{\circ} \mathrm{C}\right.$ for 24 hours). The solid substrate $(5.0 \mathrm{~g})$ was placed in $250 \mathrm{~mL}$ erlenmeyer flasks and sterilized at $121^{\circ} \mathrm{C}$ for $20 \mathrm{~min}$. A volume equivalent to $10^{7}$ spores $/ \mathrm{mL}$ or $5 \mathrm{~g}$ equivalent of dry mycelial biomass per gram of substrate of each culture was used as inoculum and suspended in a nutrient solution composed of $(\mathrm{g} / \mathrm{L}):\left(\mathrm{NH}_{4}\right){ }_{2} \mathrm{SO}_{4}, 3.5$; $\mathrm{KH}_{2} \mathrm{PO}_{4}, 3.0 ; \mathrm{MgSO}_{4} 7 \mathrm{H}_{2} \mathrm{O}, 0.5 ; \mathrm{CaCl}_{2}, 0.5$ and Tween 80 $(1.0 \% \mathrm{v} / \mathrm{v})$. Additionally, $20 \mathrm{~mL}$ of the same nutrient solution were added to each flask (around $60 \%$ of humidity).

The fermentation was performed at $45^{\circ} \mathrm{C}$ for seven days for the thermophilic strains and at $30^{\circ} \mathrm{C}$ for 14 days for mesophilic strains. At intervals of 24 (thermophilic) or 48 hours (mesophilic), two flasks were taken and the fermented material was solubilized in $100 \mathrm{~mL}$ of distilled water, stirred for 1 hour, filtered and centrifuged at $10000 \mathrm{x} \mathrm{g}$, at $4{ }^{\circ} \mathrm{C}$. The supernatant was used as the crude enzymatic extract. All the experiments were carried out in duplicate.

\section{Enzymatic assays}

Five important hydrolytic enzymes were assayed: avicelase, carboxymethylcellulase and $\beta$-glucosidase (cellulases) and $\beta$-xylosidase and xylanase (hemicellulases).

Endoglucanase (CMCase) and avicelase activities were determined according to Moretti et al. (2012), with some modifications. Reaction mixtures containing $10 \mu \mathrm{L}$ of crude enzyme and $90 \mu \mathrm{L}$ of sodium acetate buffer $0.1 \mathrm{M}, \mathrm{pH}$ 5.0, containing carboxymethylcellulose (1\%) or avicel $(1 \%)$, respectively, were incubated at $60{ }^{\circ} \mathrm{C}$ for thermotolerant or at $40{ }^{\circ} \mathrm{C}$ for mesophilic strains, for $10 \mathrm{~min}$. The released reducing sugars were quantified by DNS (3.5-dinitrosalicylic acid) method (Miller, 1959), using a glucose standard curve. One unit of enzyme activity (U) was defined as the amount of enzyme required to release one $\mu \mathrm{mol}$ of reducing sugar per minute under assay conditions. The $\beta$-glucosidase activity (cellobiase activity) was determined in reaction mixtures composed of $50 \mu \mathrm{L}$ of crude enzyme extract, $250 \mu \mathrm{L}$ of sodium acetate buffer $(0.1$ $\mathrm{M} ; \mathrm{pH} 5.0)$ and $250 \mu \mathrm{L}$ of 4-nitrophenyl- $\beta$-Dglucopyranoside $(4 \mathrm{mM})$, (PNPG, Sigma), with incubation for $10 \mathrm{~min}$ at $60{ }^{\circ} \mathrm{C}$ for thermophilic strains or at $40{ }^{\circ} \mathrm{C}$ for mesophilic strains (Baffi et al., 2011). The reaction was stopped by the addition of $2.0 \mathrm{~mL}$ of $2 \mathrm{M} \mathrm{Na}_{2} \mathrm{CO}_{3}$. One unit of enzyme activity $(\mathrm{U})$ was defined as the amount of enzyme required to release one $\mu \mathrm{mol}$ of $p$-nitrophenol per minute in the assay conditions.

Xylanase activity was determined by the same methods described for endoglucanase (CMCase) and avicelase activities, except that xylan (from Beechwood) at $1 \%$ was used as substrate. The released reducing sugars were quantified by DNS method, using a xylose standard curve. One unit of enzyme activity (U) was defined as the amount of enzyme required to release one $\mu \mathrm{mol}$ of xylose per minute under assay conditions. The $\beta$-xylosidase activity was determined by the same method described for $\beta$-glucosidase activity, except that 4-nitrophenyl- $\beta$-D-xylopyranoside $(4 \mathrm{mM})$ (PNPX, Sigma) was used as substrate. One unit of 
enzyme activity (U) was defined as the amount of enzyme required to release one $\mu \mathrm{mol}$ of $p$-nitrophenol per minute in the assay conditions. Reaction mixtures without adding enzymatic extract were used as negative controls.

\section{Physico-chemical characterization}

The optimum $\mathrm{pH}$ was measured by incubating reaction mixtures at $60{ }^{\circ} \mathrm{C}$ for thermophilic or at $40{ }^{\circ} \mathrm{C}$ for mesophilic strains, for $10 \mathrm{~min}$, using buffer solutions containing a pH range from 3.0 to 8.0 , ranging from 0.5 to 0.5 . The buffers used were: acetate buffer (pH 3.0 to 5.5); citrate / phosphate buffer (pH 5.5 at 7.0), and Tris / $\mathrm{HCl}(\mathrm{pH} 7.0$ at 8.5). In order to evaluate the optimum temperature of the enzymes, assays were carried out by incubating the reaction mixture at temperatures ranging from 30 to $80^{\circ} \mathrm{C}$ (varying from 5 to $5{ }^{\circ} \mathrm{C}$ ), at the optimum $\mathrm{pH}$.

To determine the $\mathrm{pH}$ stability, the extracts were diluted with acetate buffer at a $\mathrm{pH}$ range between 3.0 and 8.0, and incubated at room temperature for 24 hours. After this period, the residual enzymatic activity was quantified in optimum $\mathrm{pH}$ and temperature. To evaluate the thermostability, the enzymatic extracts were incubated for 1 hour at temperatures ranging from 30 to $80^{\circ} \mathrm{C}$. After this period, the residual enzymatic activity was measured in optimum $\mathrm{pH}$ and temperature.

The effect of ethanol on the activity of the enzymes was also evaluated in the optimal $\mathrm{pH}$ and temperature, using increasing concentrations of ethanol in the reaction mixture (0-40\%). Likewise, the enzyme activity in the presence of sugars (glucose or xylose) was evaluated.

All assays were performed in duplicate.

\section{Results and Discussion}

\section{Isolation and identification}

A total of 19 filamentous fungi and seven yeast strains were isolated from piles of sugarcane bagasse from the Cerrado region of Brazil (mesoregion of Triângulo Mineiro and Alto Paraíba, Minas Gerais) under thermophilic and mesophilic conditions. The isolated strains were submitted to amplification of the rDNA ITS/26S regions and a representative amplicon of each strain was selected to for gene sequencing. High-quality sequences were obtained and analyzed using the BLASTn tool. Consensus sequence alignments which exhibited at least $99 \%$ similarity with published sequences in GenBank were considered to belong to the same species. Four representative species were identified: Kluyveromyces marxianus (thermophilic), Aspergillus niger (mesophilic), Aspergillus sydowii (mesophilic) and Aspergillus fumigatus, which was isolated from both temperature conditions (Table 1). Upon BLASTn analysis, some fungal sequences were found to exhibit relatively low levels of similarity (below 97\%) with Genbank published sequences. These strains were identified based on morphological characteristics up to genus
Table 1 - Molecular identification of fungi isolated from sugar cane bagasse piles.

\begin{tabular}{|c|c|c|c|c|}
\hline Species & Strain & $\begin{array}{l}\text { PCR product } \\
\text { (bp) }\end{array}$ & $\begin{array}{c}\text { Acession } \\
\text { number }\end{array}$ & $\begin{array}{c}\text { Frequency } \\
(\%)\end{array}$ \\
\hline \multirow{10}{*}{$\begin{array}{l}\text { Aspergillus } \\
\text { fumigatus }\end{array}$} & SCB4 & 600 & KC936269 & \multirow[t]{10}{*}{59} \\
\hline & SBC6 & 550 & KF003422 & \\
\hline & SBC7 & 600 & KF003423 & \\
\hline & $\mathrm{SBC} 10$ & 550 & KF003424 & \\
\hline & $\mathrm{SBC} 12$ & 550 & KF003425 & \\
\hline & SBC16 & 600 & KF003426 & \\
\hline & L8 & 600 & KF049781 & \\
\hline & SBCM5 & 600 & KF003429 & \\
\hline & SBCM8 & 600 & KF003431 & \\
\hline & SBCM12 & 600 & KF003432 & \\
\hline \multirow{4}{*}{$\begin{array}{l}\text { Kluyveromyces } \\
\text { marxianus }\end{array}$} & $\mathrm{L} 1$ & 800 & KF049777 & \multirow[t]{4}{*}{24} \\
\hline & L3 & 1000 & KF049778 & \\
\hline & L4 & 800 & KF049779 & \\
\hline & L6 & 1000 & KF049780 & \\
\hline \multirow[t]{2}{*}{ Aspergillus niger } & SBCM3 & 800 & KF003427 & \multirow[t]{2}{*}{12} \\
\hline & SBCM4 & 800 & KF003428 & \\
\hline $\begin{array}{l}\text { Aspergillus } \\
\text { sydowii }\end{array}$ & SBCM7 & 700 & KF003430 & 6 \\
\hline
\end{tabular}

level. Macro- and microscopic analyses allowed the classification of such strains as belonging to the genus Aspergillus (SBC2, 5, 9, 13, 14, M1, M2 strains). Some strains (L2, L5 and L7) did not presented satisfactory sequences and identification was not possible.

The low number of species isolated from sugarcane bagasse could be due to the increase in temperature during the decomposition of this waste, which can provide a succession of mesophilic to thermotolerant strains. Moretti et al. (2012) reported that few fungi species have been described from environments where high temperatures are shown. Furthermore, the lignocellulosic biomass in this residue can also limit the number of microorganisms, restricting the presence of species which are not able to produce hydrolytic enzymes (Moretti et al., 2012). The results also indicated a predominance of strains from the Aspergillus genus in this environment. Aspergilli strains with environmental and economical importance have previously been described (Baffi et al., 2012; Souza et al., 2012). Strains from this genus are also known as good producers of extracellular enzymes, giving these microorganisms great potential for growth in wastes (Jaafaru et al., 2007; Gottschalk et al., 2013).

The predominant isolated species was Aspergillus fumigatus (59\%), an ubiquitous fungus commonly found in agricultural byproducts (Souza et al., 2012). This species is one of a wide range of fibrolytic enzyme-producing organisms, and some strains have been described as having great potential for cellulase and hemicellulase production 
(Moretti et al., 2012). The second most frequently isolated species was the yeast Kluyveromyces marxianus, with a frequency of $24 \%$. This yeast is known as having a facility to grow in different substrates and in high temperatures (Foukis et al., 2012). Several biotechnological applications have been associated with this species, such as production of enzymes, ethanol, reduction of lactose content in food products, production of bio-ingredients from cheese whey and many others (Fonseca et al., 2008; Arrizon et al., 2012). Aspergillus niger strains were isolated at a lower frequency $(12 \%)$. This species is well known as an enzyme source for several industrial processes (Pawar and Thaker, 2009). Bansal et al. (2012) analyzed various agricultural and kitchen wastes to support the production of cellulases by a strain of $A$. niger isolated from decaying residues and obtained appreciable levels of different cellulases. The ethanol production using crude enzymatic complexes produced by $A$. niger and agro-industrial biomass has also been described (Rocha et al., 2013). Lastly, Aspergillus sydowii was the least frequent species $(6 \%)$. This fungus has been isolated in either marine or land environments and enzyme production with biotechnological applications has also been reported (Polizeli et al., 2005). In a recent study, Matkar et al. (2013) isolated a terrestrial strain of $A$. sydowii from composting sites which was found to be a potential $\beta$-glucosidase producer.

\section{Enzyme production}

Amongst the isolates, three strains were selected as good producers of $\beta$-glucosidase, $\beta$-xylosidase and xylanase after solid state fermentation (SSF): A. sydowii SBCM7, A niger SBCM3 and A. fumigatus SBC4. For other enzymes, significant enzymatic production was not observed under the described conditions.

A. sydowii SBCM7 produced good levels of $\beta$-glucosidase $(60 \mathrm{U} / \mathrm{g})$, but low values of for $\beta$-xylosidase $(9 \mathrm{U} / \mathrm{g})$ and xylanase $(19 \mathrm{U} / \mathrm{g})$. The peaks of production occurred at 240, 144 and 96 hours of SSF, respectively (Figure 1). The production of xylanase by this species was reported (Nair et al., 2010). In a recent study, an A. sydowii strain isolated from composting sites was able to produce endoglucanase, exoglucanase and $\beta$-glucosidase (Matkar et al., 2013). However, the production of $\beta$-glucosidase was lower than in our study.

The $A$ niger SBCM3 strain exhibited peaks of maximum production for $\beta$-glucosidase ( $54 \mathrm{U} / \mathrm{g}$ ), $\beta$-xylosidase $(73 \mathrm{U} / \mathrm{g})$ and xylanase activities ( $39 \mathrm{U} / \mathrm{g})$ after 240,144 and 48 hours of SSF, respectively (Figure 2). Xylanase production was lower than those reported in literature. Higher levels of xylanase activity were obtained (4465 $\pm 52 \mathrm{IU} / \mathrm{gds})$ after SSF, using wheat bran and soybean cake as substrates (Pal and Khanum, 2010). On the other hand, $\beta$-glucosidase production was higher than in other studies (Bansal et al., 2012). In addition, the SBCM3 strain was found to be a po-

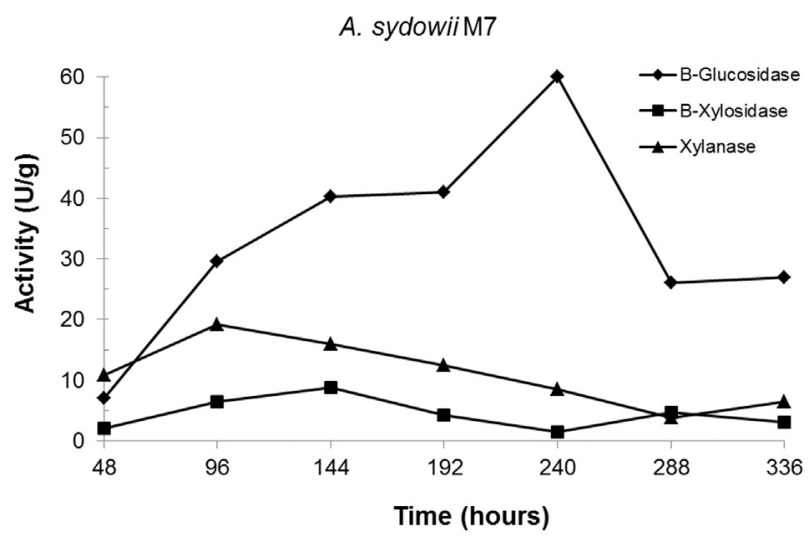

Figure 1 - Kinetics of enzyme production by A. sydowii SBCM7 strain. Enzymatic activity was expressed as U/g. Results are mean values from triplicate experiments.

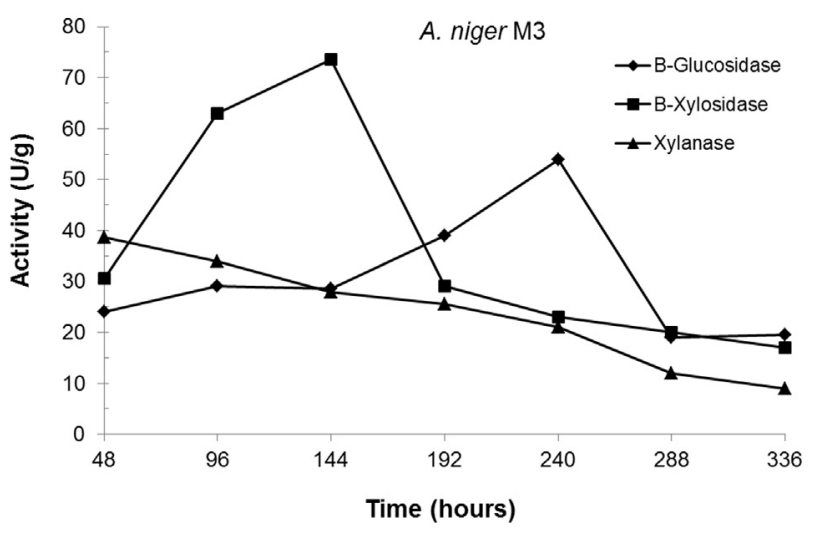

Figure 2 - Kinetics of enzyme production by A. niger SBCM3 strain. Enzymatic activity was expressed as U/g. Results are mean values from triplicate experiments.

tential $\beta$-xylosidase producer showing high activity (73 U/g). Lower values of $\beta$-xylosidase were obtained by other species (Dogaris et al., 2009; Oliveira et al., 2014). In a similar study carried out with an $A$. niger strain isolated from copra paste, the $\beta$-xylosidase could not be detected in the crude extract (Díaz-Malváez et al., 2013). These data indicate $A$. niger $\mathrm{SBCM} 3$ as a very good $\beta$-xylosidase- and $\beta$-glucosidase-producing strain.

A. fumigatus SBC4 strain was the best producer of $\beta$-glucosidase and xylanase (with peaks of activity of $54 \mathrm{U} / \mathrm{g}$ and $573 \mathrm{U} / \mathrm{g}$ after 96 and 24 hours of SSF, respectively) (Figure 3). Delabona et al. (2012) obtained a lower production of $\beta$-glucosidase ( $38 \mathrm{U} / \mathrm{g}$ ) by an A. fumigatus strain (P40M2) after 96 hours under the same conditions. On the other hand, the strain P40M2 exhibited a superior xylanase activity $(821 \mathrm{U} / \mathrm{g})$. In a recent study, Moretti et al. (2012) also observed a higher xylanase production $(1040 \mathrm{U} / \mathrm{g})$, using a mix of sugarcane and wheat bran. Thus, though the xylanase production was smaller than in previ- 


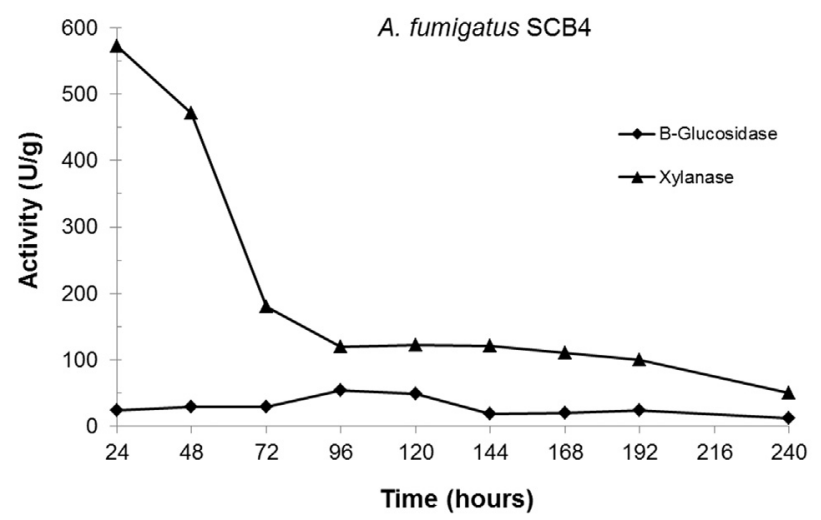

Figure 3 - Kinetics of enzyme production by A. fumigatus SCB4 strain. Enzymatic activity was expressed as U/g. Results are mean values from triplicate experiments.

ous reports, A. fumigatus $\mathrm{SBC} 4$ showed a good potential for $\beta$-glucosidase production.

Regarding the yeast $K$. marxianus, no enzymatic activity was detected after SSF according to the growth conditions described in the "Material and Methods" section (data not shown). Experiments under submerged fermentation using different combinations of substrates might be conducted in further studies in order to investigate its enzyme production potential.

\section{Physico-chemical characterization of the selected extracts}

The physicochemical properties of crude extracts that exhibited the highest enzymatic activities were characterized as follows: $\beta$-glucosidase extract from $A$. sydowii SBCM7 (M7- $\beta$-glu), enzymatic extract from $A$. niger SBCM3 with high production of $\beta$-xylosidase and $\beta$-glucosidase (M3- $\beta$-xyl and M3- $\beta$-glu) and the extract from $A$. fumigatus SBC4 containing both xylanase (AF4-xyl) and $\beta$-glucosidase (AF4- $\beta$-glu) activities.

The $\beta$-glucosidase from $A$. sydowii SBCM7 (M7$\beta$-glu) exhibited maximum activity at $\mathrm{pH} 4.5$ and at $50-55{ }^{\circ} \mathrm{C}$ (Table 2). Similar profiles were obtained by Madhu et al. (2009), with optimal activity at pH 5.0 and $50^{\circ} \mathrm{C}$. The enzyme was stable at around $\mathrm{pH} 4.0-6.5$ and up to $45^{\circ} \mathrm{C}$, showing a typical profile of enzymes from mesophilic strains. Moreover, it was tolerant up to $10 \%$ of ethanol and $100 \mathrm{mM}$ of glucose. The tolerance to glucose is remarkable for biotechnological applications, since the majority of microbial $\beta$-glucosidases reported in the literature are inhibited by this sugar (Baffi et al., 2011; 2013).

M3- $\beta$-xyl from A. niger SBCM3 showed an optimal $\mathrm{pH}$ of 3.0 and stability in the range of $\mathrm{pH} 4.0-7.0$ (Table 2). This enzyme exhibited two peaks of optimum temperature at 55 and $70{ }^{\circ} \mathrm{C}$, suggesting the presence of isozymes. $\beta$-xylosidases with elevated optimum temperatures were reported for other A. niger strains (Díaz-Mal-

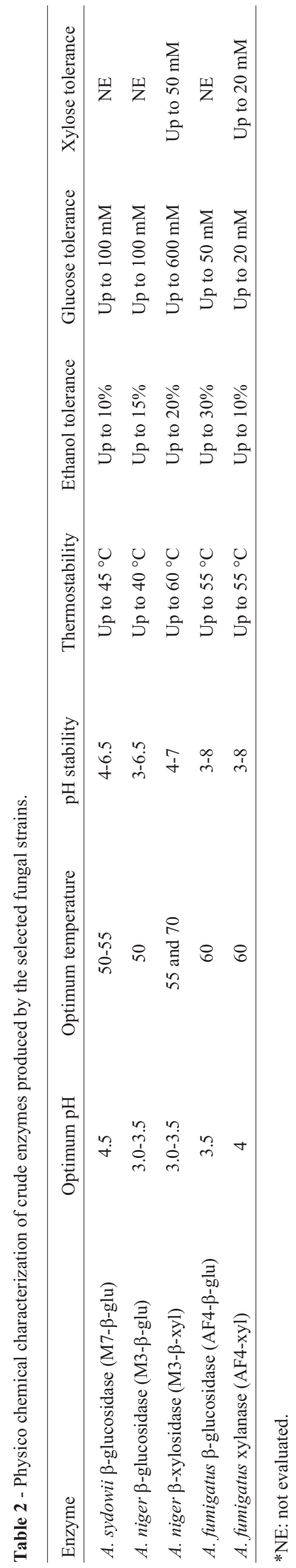


váez et al., 2013). At optimal conditions $\left(55^{\circ} \mathrm{C}\right.$ and $\mathrm{pH}$ 3.0), a high level of $\beta$-xylosidase activity was obtained (141 U/g of dry substrate). This value of activity was higher than in other studies (Díaz-Malváez et al., 2013). Furthermore, M3- $\beta$-xyl maintained $85 \%$ of residual activity after incubation at $60{ }^{\circ} \mathrm{C}$ for 1 hour (Table 2), showing higher thermostability than that previously reported (Benassi et al., 2013). This thermostability could be of special interest for application in large-scale industrial processes that may be subject to temperature variations (Moretti et al., 2012). M3- $\beta$-xyl was tolerant to xylose up to $50 \mathrm{mM}$ (Table 2). These results differ to those reported by Benassi et al. (2013), which described a $\beta$-xylosidase with atolerance of up to $100 \mathrm{mM}$ of xylose. With regard to glucose, M3- $\beta$-xyl was not inhibited, preserving about $78 \%$ of residual activity at $600 \mathrm{mM}$ of glucose (Table 2). In addition, at $100 \mathrm{mM}$, this sugar stimulated the $\beta$-xylosidase activity. Higher values of inhibition by glucose have been reported (Benassi et al., 2013). In addition, the enzyme was very tolerant up to $20 \%$ of ethanol, reinforcing the potential application of this A. niger $\beta$-xylosidase in hydrolysis processes.

M3- $\beta$-glu exhibited some similar properties with M3- $\beta$-xyl (optimal activity at $\mathrm{pH} 3.0-3.5$ and at $50^{\circ} \mathrm{C}$, high stability between $\mathrm{pH} 3.0-6.5$ and up to $15 \%$ of ethanol). However, it was stable up to $40{ }^{\circ} \mathrm{C}$ and $100 \mathrm{mM}$ of glucose (Table 2). These related characteristics of both enzymes emphasize the simultaneous use of a single crude enzymatic extract from $A$. niger $\mathrm{SBCM} 3$ containing both activities, which could be fairly appreciable for a better efficiency in biomass degradation.

Maximum activities were obtained at $\mathrm{pH} 4.0$ and 3.5 for xylanase (AF4-xyl) and $\beta$-glucosidase (AF4- $\beta$-glu) from the A. fumigatus SBC4 strain, respectively (Table 2), revealing typical profiles of acidophilic enzymes. Studies showing acidic xylanases have been reported (Souza et al., 2012). Moretti et al. (2012) observed an optimum $\mathrm{pH}$ of 4.5-5.0 for a xylanase from A. fumigatus isolated from sugarcane bagasse. Previous works also suggested acid optimum $\mathrm{pHs}$ for $\beta$-glucosidases (Delabona et al., 2012; Baffi et al., 2013). Both enzymes were stable throughout the $\mathrm{pH}$ range of 3.0-8.0 (Table 2), with higher $\mathrm{pH}$ stability than in other studies (Moretti et al., 2012; Baffi et al., 2013). The enzymes AF4-xyl and AF4- $\beta$-glu showed an optimum temperature of $60{ }^{\circ} \mathrm{C}$ and high stability up to $55^{\circ} \mathrm{C}$ (Table 2). These results strongly suggest that these AF4-xyl and AF4- $\beta$-glu enzymes seem to be thermophilic, which could be useful for many biotechnological processes that work in high temperatures. In addition, these similar profiles indicate that a single crude extract containing both xylanase and $\beta$-glucosidase activities could be applied during the saccharification processes, functioning properly in acid conditions and elevated temperatures. Consequently, the characteristics of the culture medium could be maintained more easily to achieve high sugar yields, avoiding additional procedures.

AF4- $\beta$-glu was active up to $30 \%$ of ethanol, demonstrating good tolerance to this compound. However, AF4xyl was stable up to $10 \%$ of ethanol (Table 2). Both crude enzymes were inhibited by glucose, with tolerance up to 20 (AF4-xyl) and $50 \mathrm{mM}$ (AF4- $\beta$-glu) of this sugar, respectively (Table 2). AF4-xyl was also inhibited at low concentrations of xylose (Table 2).

\section{Conclusions}

This work reported the molecular identification of the fungal microbiota isolated from sugarcane bagasse piles from the Brazilian Cerrado and their potential as sources of lignocellulose-degrading enzymes. Three Aspergilli strains were selected as good producers of $\beta$-glucosidase, $\beta$-xylosidase and xylanase. Among them, A. niger SBCM3 strain was the best producer of $\beta$-xylosidase, with suitable characteristics for industrial applications, such as acid optimum $\mathrm{pH}$, thermostability and tolerance to glucose. This strain was also able to produce high $\beta$-glucosidase activity with some similar properties to those detected for $\beta$-xylosidase. A. fumigatus SBC4 strain was selected as the best $\beta$-glucosidase and xylanase producer. Both enzymes exhibited appropriate features for application in procedures of plant biomass reuse, such as optimal activity at acid $\mathrm{pH}$ and high temperatures, thermostability, $\mathrm{pH}$ stability and tolerance to ethanol. These equivalent properties of the selected enzymatic preparations suggest their promising synergistic use in cocktails in future research on the saccharification of vegetal residues, involving the fabrication of bioproducts with aggregate value, such as ethanol production. Further studies will investigate the combined action of these extracts in the hydrolysis of lignocellulosic biomass from residues.

\section{Acknowledgments}

This research was supported by the National Counsel of Technological and Scientific Development (CNPq) and Federal University of Uberlândia (Propp-UFU). B.S.L. dos Santos thanks to the Minas Gerais State Foundation for Research Development (Fapemig) for her studentship. A.F.S. Gomes, e.g. Fransciscon and J.M. Oliveira are grateful to $\mathrm{CNPq}$ for their student grants.

\section{References}

Arrizon J, Morel S, Gschaedler A et al. (2012) Fructanase and fructosyltransferase activity of non-Saccharomyces yeasts isolated from fermenting musts of mezcal. Bioresour Technol 110:560-565.

Baffi MA, Bezerra CS, Villena MA et al. (2010) Isolation and molecular identification of wine yeasts from a Brazilian vineyard. Ann Microbiol 61:75-78. 
Baffi MA, Tobal T, Lago JG et al. (2011) A Novel ß-Glucosidase from Sporidiobolus pararoseus: Characterization and Application in Winemaking. J Food Sci 76:C997-C1002.

Baffi MA, Romo-Sanchez S, Ubeda-Iranzo J et al. (2012) Fungi isolated from olive ecosystems and screening of their potential biotechnological use. New Biotechnol 29:451-456.

Bansal N, Tewari R, Soni R et al. (2012) Production of cellulases from Aspergillus niger NS-2 in solid state fermentation on agricultural and kitchen waste residues. Waste Manage 32:1341-1346.

Castellani A (1939) Viability of some pathogenic fungi in distilled water. J Trop Med Hyg 24:270-276.

Delabona PS, Pirota RDPB, Codima CA et al. (2012) Using Amazon forest fungi and agricultural residues as a strategy to produce cellulolytic enzymes. Biomass Bioenerg 37:243250.

Fonseca GG, Heinzle E, Wittmann C et al. (2008) The yeast Kluyveromyces marxianus and its biotechnological potential. Appl Biochem Microb 79:339-354.

Foukis A, Stergiou PY, Theodorou LG et al. (2012) Purification, kinetic characterization and properties of a novel thermotolerant extracellular protease from Kluyveromyces marxianus IFO 0288 with potential biotechnological interest. Bioresour Technol 123:214-220.

Gottschalk LMF, Paredes RS, Teixeira RSS et al. (2013) Efficient production of lignocellulolytic enzymes xylanase, _-xylosidase, ferulic acid esterase and -glucosidase by the mutant strain Aspergillus awamori 2B.361 U2/1. Braz J Microbiol 44: 569-576.

Jaafaru MI, Fagade OE (2007) Cellulase Production and Enzymatic Hydrolysis of Some Selected Local Lignocellulosic Substrates by a Strain of Aspergillus niger. Res J Biol Sci 2:13-16.

Martins LF, Kolling D, Camassola M et al. (2008) Comparison of Penicillium echinulatum and Trichoderma reesei cellulases in relation to their activity against various cellulosic substrates. Bioresour Technol 99:1417-1424.

Matkar K, Chapla D, Divecha J et al. (2013) Production of cellulase by a newly isolated strain of Aspergillus sydowii and its optimization under submerged fermentation. Int Biodeter Biodegr 78:24-33.

Miller GL (1959) Use of dinitrosalicylic acid reagent for determination of reducing sugar. Anal Chem 31:426-428.

Moretti MMS, Martins DAB, Da Silva R et al. (2012) Selection of thermophilic and thermotolerant fungi for the production of cellulases and xylanases under solid-state fermentation. Braz J Microbiol 43:1062-1071.

Nair SG, Sindhu R, Shashidhar S (2010) Enzymatic bleaching of kraft pulp by xylanase from Aspergillus sydowii SBS 45. Indian J Microbiol 50:332-338.

Pal A, Khanum F (2010) Production and extraction optimization of xylanase from Aspergillus niger DFR-5 through solidstate-fermentation. Bioresour Technol 101:7563-7569.

Pawar VC, Thaker VS (2009) Acid phosphatase and invertase activities of Aspergillus niger. Mycosci 50:323-330.

Pitt JI, Hocking AD (1997) Fungi and Food Spoilage. Black Academic \& Professional - Chapman \& Hall, London.

Polizeli MLTM, Rizzatti ACS, Monti R et al. (2005) Xylanases from fungi: properties and industrial applications. Appl Biochem Microb 67:577-591.

Rocha NRAF, Barros MA, Fischer J et al. (2013) Ethanol production from agroindustrial biomass using a crude enzyme complex produced by Aspergillus niger. Renew Energ 57:432-435.

Souza DT, Bispo AS, Bon EP et al. (2012) Production of thermophilic endo-beta-1,4-xylanases by Aspergillus fumigatus FBSPE-05 using agro-industrial by-products. Appl Biochem Biotech 166:1575-1515.

Associate Editor: Eleni Gomes

All the content of the journal, except where otherwise noted, is licensed under a Creative Commons License CC BY-NC. 